\title{
サイクラミン酸ナトリウムのガスクロマトグラフィー
}

(昭 和 42 年 5 月 20 日 受 理)

$$
\text { 井上哲男 }{ }^{* 1} \text { 加 藤三郎 }{ }^{* 1} \text { 大河原 晃 }{ }^{* 2}
$$

\section{Gas Chromatography of Sodium Cyclamate}

\author{
Tetsuo INOUE*1, Saburo KATO*1 and Akira OKAWARA*2
}

(*1 National Institute of Hygienic Sciences: Tamagawayoga-machi, Setagaya-ku, Tokyo; *2 Sampo Pharmaceutical Co., Ltd.: 40, 1-chome, Shimoochiai, Shinjuku-ku, Tokyo)

Gas chromatographic procedure for the determination of sodium cyclamate was studied. According to recent studies, it has been reported that sodium cyclamate reacts with nitrite and produces cyclohexanol, cyclohexanone and cyclohexene. The author's experiment showed that the major product of the reaction was cyclohexyl nitrite, together with some cyclohexanol and slight cyclohexene in the presence of excess nitrite at temp. below $5^{\circ} \mathrm{C}$.

Using the blended liquid phase column consisting of DC-550 and DEGS (10\% of each) on Gaschrom $\mathrm{P}(60 / 80 \mathrm{mesh})$ at $60^{\circ} \mathrm{C}$, carrier gas nitrogen $(60 \mathrm{ml} / \mathrm{min})$ and a flame ionization detector, cyclohexyl nitrite and cyclohexanol were investigated. The results are given in Fig. 1-(C) and 2.

Sodium cyclamate was determined on the basis of the cyclohexyl nitrite. The cyclohexyl nitrite was prepared by treating varying amounts of sodium cyclamate with $5 \mathrm{ml}$ of $10 \%$ sodium nitrite and $4 \mathrm{ml}$ of $10 \%$ sulfuric acid in ice water and it was extracted with $10 \mathrm{ml}$ of $n$-hexane containing $0.25 \mathrm{v} / \mathrm{v} \% n$-decane as internal standard and then injected to the Shimazu gas chromatograph.

The relation between peak heights of cyclohexyl nitrite and amounts of sodium cyclamate was linear in the range of $20 \sim 600 \mathrm{mg}$ of the latter, and in this case, cyclohexanol did not appeared. But, when excessive amounts $(>800 \mathrm{mg})$ of sodium cyclamate were present, the yield of cyclohexyl nitrite diminished and that of cyclohexanol increased. The minimum limit of detection was approximately $0.1 \mu \mathrm{g}$ as sodium cyclamate.

(Received May 20, 1967)

\section{まえがき}

サイクラミン酸ナトリウムの定量法については,すで に数多くの報告がなされている.すなわち, クロラニル による呈色反応, 過酸化水素の存在下に塩酸によって加 水分解して生ずるシクロヘキシルアミンとキンヒドロン との呈色反応, ポーラログラフによる方法, サッカリ ソ，ズルチンなどとの分離定量法，および赤外吸収ス ペクトル測定法による定量法などがある1)。 また公定 法2)としては，亜硝酸を反応させて生成する硫酸イオン を EDTA で滴定する方法が採用されている.

われわれは，ガスクロマトグラフィーによるサイクラ

*1 国立衛生試験所食品添加物部：東京都世田谷区互 川用贺町 2-203

*2 三宝製薬 (株) 研究室 : 東京都新宿区下落合 1-40
ミン酸ナトリウムの定量法の可能性について検討を試み た. サイクラミン酸のガスクロマトグラフィーとして は，遊離酸をジアゾメタンでメチルェステルとして行 ならことができると述べた報告もあるが゙，塩類につい ては困難と思われる．樋ロら"によるとそのナトリウ 么塩は亜硝酸イオンの存在下において, 高温, 高王状態 ではシクロへキセンが生成し，同時に生成が予想された シクロヘキサノール, シクロヘキシルアミンは全く検出 されなかったと報告している．また Rees ${ }^{51}$ ならびに Richardson および Luton ${ }^{6)}$ は亜硝酸の作用によって生 ずるシクロへキセンによってサイクラミン酸を定量して いる. 後者は, 塩酸を用いるとモノクロロシクロへキサ ンを副生するから硫酸を用いた方がよいと述べている. さらに Derse および Daun ${ }^{7)}$ は過酸化水素を作用させ 
て生ずるシクロヘキシルアミンのアルカリカラムによる ガスクロマトグラフィーを報告しているが，これらの報 告はいずれも Cyclohexyl nitrite (以下 C. N. と略す) のピークについてはふれていない.

井上ら”はさきにサイクラミン酸塩と亜硝酸を氷冷時 反応させ，生成する C. N. の赤外吸収スペクトルを用い て定量する方法を報告した，われわれはこれをさらに， ガスクロマトグラフィーを用いてその性状を検討し, 定 量にも応用しらることを見いだしたので報告する。

\section{I 実験方法}

1. 装置およびカラム

ガスクロマトグラフ : 島津 GC-1C 型および付属水素 炎イオン化検出器 FID-1B 型.

カラム：主としてつぎのカラムを使用した。

(1) DC-550 (10\%): Silicone oil DC-550 Anakrom (acid washed 60 80 mesh) にコーティングした ものを, 内径 $4 \mathrm{~mm} \times 150 \mathrm{~cm}$ のステンレスU 字管に充 填した.

(2) DEGS (25\%): Diethylene glycol succinate Gaschrom P (60 80 mesh) にコーティングしたもの を, 内径 $4 \mathrm{~mm} \times 150 \mathrm{~cm}$ のステンレス U 字管に充填し た.

(3) PEGS $(25 \%)$ : Polyethylene glycol succinate を用いて（2）と同様に作製し充媜した。

(4) DC-550+DEGS $\{(10+10) \%\}: D C-550$ と DEGS の混合アセトン溶液から蒸発法により Gaschrom P (60 80 mesh) にコーティングしたものを, 内径 $4 \mathrm{~mm}$ $\times 150 \mathrm{~cm}$ のステンレス U 字管に充填した.

(5) TCP (15\%): Tricresyl phosphate Daichrom C (80 100 mesh) にコーティングしたものを内径 $3 \mathrm{~mm} \times 112.5 \mathrm{~cm}$ のステンレス U 字管に充填した.

(6) $\mathrm{QF}-1(10 \%)$ : Silicone DC.QF-1 を Gaschrom $\mathrm{P}(60 \sim 80 \mathrm{mesh})$ にコーティングしたものを, 内径 $3 \mathrm{~mm}$ $\times 150 \mathrm{~cm}$ のステンレス U 字管に充填した.

\section{2. 標準試料および試薬}

サイクラミン酸ナトリウムおよびサッカリンナトリウ 么：食品添加物公定書2) 合格品.

炭酸水素ナトリウム, 塩化ナトリウムおよびトウモロ コシデンプン：日本薬局方品（第 7 改正).

$n$ ーデカン (bp $\left.174^{\circ}\right)$, シクロへキセン (bp $\left.83^{\circ}\right)$, シク ロヘキサノール $\left(\mathrm{bp} 161^{\circ}\right)$ シクロへキサノン (bp155.6 $)$ および脂肪酸メチルェステル : 東京化成 $\mathrm{KK}$ 製.

$n$-ヘキサン $\left(\mathrm{bp} 69^{\circ}\right)$, アルュール類 : 市販試薬特級を 再留して使用した。

$n$ ーアルコール亜硝酸エステル：対応する $n$-アルコー ルから合成した。

$10 \% \mathrm{NaNO}_{2}, 10 \% \mathrm{H}_{2} \mathrm{SO}_{4}$ : 試薬特級を用いて調製し た.

3. 検液の調製法
井上らがすでに報告した方法1に準じて行なった。す なわちサイクラミン酸ナトリウム $100 \mathrm{mg}$ 相当量を 50 $\mathrm{ml}$ の共栓遠心沈殿管に正確にひょ 5 取し，蒸留水 $5 \mathrm{ml}$ を加えてよく混和し，メチルレッド試液を指示薬として $10 \% \mathrm{H}_{2} \mathrm{SO}_{4}$ で中和したのち，50を越えない水水中で $10 \% \quad \mathrm{NaNO}_{2}$ 溶液 $5 \mathrm{ml}$ および $10 \% \mathrm{H}_{2} \mathrm{SO}_{4} 4 \mathrm{ml}$ を加 え，ときどき振り混ぜながら 1 時間放置する。つぎに塩 化ナトリウム $4.5 \mathrm{~g}$ を添加し, 内部標準として $n$-デカ ン $(0.25 \mathrm{v} / \mathrm{v} \%)$ を含んだ $n$ 一へキサンを正確に $10 \mathrm{ml}$ 加 え, センをして 3 分間振と $5 し$, 遠心分離 (3000 r. p. m, $3 \mathrm{~min})$ したのち， $n$-へキサン層を分取し無水硫酸ナト リウムを加えて脱水し検液とする。

\section{III実験結果および考察 \\ 定性}

1. カラムの比較

無極性カラムとして DC-550 カラム, 極性カラムとし て DEGS カラムおよび PEGS カラム, 中間極性カラム として TCP カラム, QF-1 カラムおよび DC-550+ DEGS の配合液相カラムを作成し, サイクラミン酸ナト リウムおよび関連化合物のクロマトグラムを作製し比較 検討した。 クロマトグラムを Fig. 1-(A) (B) (C) に示 于.

Fig. 1-(A) は無極性カラムの例として DC-550 を液 相とする場合である. Fig. 1-(A) の上段の C. N. はサ イクラミン酸ナトリウムから悪硝酸の作用によって生成 されたもので, これはシクロへキサノールに亜硝酸を作 用させた場合のピークと一致する.nーデカンは内部標準 として添加したものであり, シクロへキサノールは市販 試薬によって得たものである. 以下 Fig. 1-(B) および (C) の場合も同様である.

Rees $^{5)}$ および Richardson, Luton ${ }^{6)}$ らはサイクラミ ン酸塩を，主としてシクロへキセンとしてガスクロマト グラフィーを行なら方法を報告している，われわれの実 験においてはシクロへキセンの生成はごくわずかで，ほ とんど C. N. となり, 後述の特殊な場合にのみシクロへ キサノールが現われている. Fig. 1-(A), (C) の下段は点 線が $n$-脂肪族アルコールで，実線はその亜硝酸エステ ルのクロマトグラムである.

Fig. 1-(B) は PEGS を液相とする場合である。一般 にポリエステルカラムでは極性物質がおくれるが，この 場合もnーデカンが速い時間に現われるのに比べ，アルコ 一ル類ははなはだ抢そく，その $\mathrm{C}_{8}$ の亜硝酸ェステルは $\mathrm{C}_{5}$ アルコール以前に現われており (Table 1 参照), シクロヘキサノールおよびC.N. はこのカラムでは $n-C_{7}$ のヘプタノールに類似した挙動を示す，遊離水酸 基を有するアルコール類は一般にテーリングが大きい が，エステルは良好なピークを示し，DC-550 カラムよ り理論段数む高い結果が得られている.

さらに極性カラムとして DEGS を液相とする場合も 


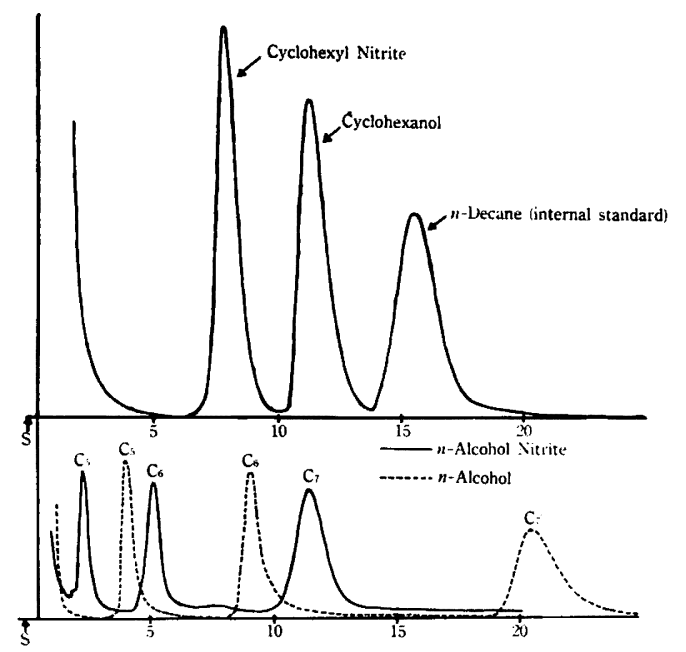

(A)

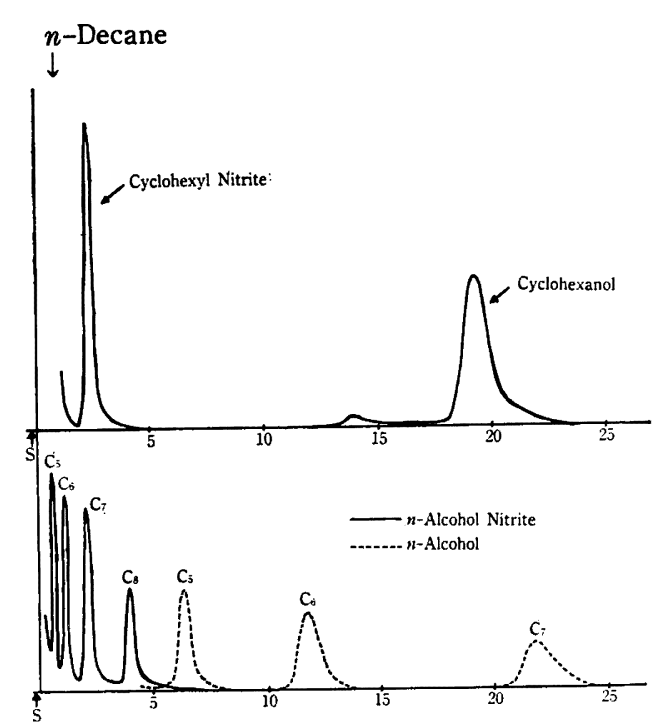

(B)

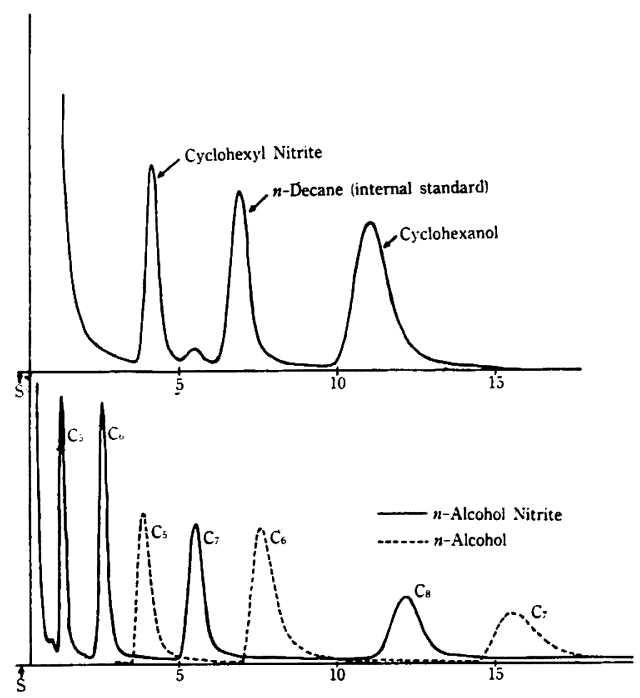

(C)

(A) Column: 10\% DC 550 on Anakrom (60/80 mesh), in $4 \mathrm{~mm} \times 150 \mathrm{~cm}$ at $60^{\circ} \mathrm{C}, \mathrm{N}_{2}$ flow $68 \mathrm{ml} / \mathrm{min}$ Detector: HFID at $150^{\circ} \mathrm{C}, \mathrm{H}_{2}$ flow $20 \mathrm{ml} / \mathrm{min}$ Inject. port: at $100^{\circ} \mathrm{C}$

(B) Column: 25\% PEGS on Gaschrom P $(60 / 80 \mathrm{mesh})$, in $4 \mathrm{~mm} \times 150 \mathrm{~cm}$ at $60^{\circ} \mathrm{C}, \mathrm{N}_{2}$ flow $60 \mathrm{ml} / \mathrm{min}$ Detector: HFID at $150^{\circ} \mathrm{C}, \mathrm{H}_{2}$ flow $20 \mathrm{ml} / \mathrm{min}$ Inject. port: at $100^{\circ} \mathrm{C}$

(C) Column: $(10+10) \%$ (DC $550+$ DEGS) on Gaschrom P $(60 / 80 \mathrm{mesh})$, in $4 \mathrm{~mm} \times 150 \mathrm{~cm}$ at $60^{\circ} \mathrm{C}, \mathrm{N}_{2}$ flow $60 \mathrm{ml} / \mathrm{min}$ Detector: $\mathrm{HFID}$ at $150^{\circ} \mathrm{C}, \mathrm{H}_{2}$ flow $20 \mathrm{ml} / \mathrm{min}$ Inject. port: at $100^{\circ} \mathrm{C}$

Fig. 1-(A) $\sim(\mathbf{C})$. Gas chromatograms of compounds produced from sodium cyclamate and nitrite, and related compounds 
Table 1. Retention Times (min) of Compounds Produced from Sodium Cyclamate and Nitrite, and Related Compounds

\begin{tabular}{|c|c|c|c|c|c|c|c|}
\hline \multirow{2}{*}{ Column } & \multirow{3}{*}{\begin{tabular}{l}
\multicolumn{1}{c}{ Liq. ph. } \\
Temp. $\left({ }^{\circ} \mathrm{C}\right)$ \\
$\mathrm{N}_{2}$ flow $(\mathrm{ml} / \mathrm{min})$
\end{tabular}} & \multirow{3}{*}{ 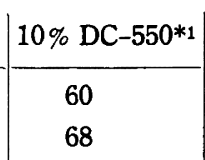 } & \multirow{3}{*}{$\begin{array}{c}25 \% \text { DEGS*2 } \\
60 \\
91\end{array}$} & \multirow{3}{*}{$\mid \begin{array}{c}25 \% \text { PEGS*2 } \\
60 \\
60\end{array}$} & \multirow{3}{*}{$\frac{(10+10) \% * 2}{(D C-550+D E G S)}$} & \multicolumn{2}{|c|}{$15 \%$ ТCP $* 8$} \\
\hline & & & & & & 60 & 110 \\
\hline Compound & & & & & & 96 & 100 \\
\hline \multicolumn{2}{|l|}{ Cyclohexene } & $2.0 \mathrm{~min}$ & 0.6 & 0.6 & 0.9 & 0.9 & 0.3 \\
\hline \multicolumn{2}{|c|}{ Cyclohexyl nitrite } & 7.8 & 3.2 & 2.7 & 3.8 & 6.2 & 1.3 \\
\hline \multicolumn{2}{|c|}{ Cyclohexanol } & 11.5 & 24.8 & 21.6 & 10.7 & 26.4 & 3.3 \\
\hline \multicolumn{2}{|l|}{ Cyclohexanone } & 14.5 & 17.3 & 15.7 & 10.7 & 19.0 & 3.1 \\
\hline \multicolumn{2}{|l|}{$n$-Decane } & 15.2 & 2.2 & 1.3 & 6.6 & 5.9 & 1.1 \\
\hline \multicolumn{2}{|c|}{ n-Alcohol $\left(\mathrm{C}_{5}\right)$ nitrite } & 2.7 & 1.0 & 0.9 & 1.2 & 1.8 & - \\
\hline \multicolumn{2}{|c|}{$\left(\mathrm{C}_{6}\right)$} & 5.3 & 1.9 & 1.6 & 2.5 & 3.8 & - \\
\hline \multicolumn{2}{|c|}{$\left(\mathrm{C}_{7}\right)$} & 11.0 & 3.6 & 2.8 & 5.4 & 8.3 & - \\
\hline \multicolumn{2}{|c|}{$\left(\mathrm{C}_{8}\right)$} & 23.3 & 7.0 & 4.8 & 11.8 & 18.5 & - \\
\hline \multicolumn{2}{|l|}{$n$-Alcohol $\left(C_{5}\right)$} & 4.1 & 8.3 & 7.2 & 3.7 & 9.6 & 1.5 \\
\hline \multicolumn{2}{|c|}{$\left(\mathrm{C}_{6}\right)$} & 8.4 & 15.7 & 13.4 & 7.3 & 22.4 & 2.7 \\
\hline \multicolumn{2}{|c|}{$\left(\mathrm{C}_{7}\right)$} & 18.3 & 29.6 & 24.6 & 15.0 & 51.8 & 5.0 \\
\hline \multicolumn{2}{|c|}{$\left(\mathrm{C}_{8}\right)$} & 39.8 & 57.5 & 44.7 & 31.0 & 118.0 & 9.3 \\
\hline \multirow{2}{*}{\multicolumn{2}{|c|}{$\begin{array}{c}n \text {-Fatty acid }\left(\mathrm{C}_{4}\right) \text { methyl ester } \\
\left(\mathrm{C}_{6}\right)\end{array}$}} & 3.2 & 2.3 & 2.0 & 1.7 & 2.3 & 0.5 \\
\hline & & 13.1 & 7.7 & 6.2 & 7.8 & 10.8 & 1.8 \\
\hline \multicolumn{2}{|c|}{$\left(\mathrm{C}_{8}\right)$} & 56.2 & 27.7 & 20.7 & 35.5 & - & 6.3 \\
\hline
\end{tabular}

$*_{1} 150 \mathrm{~cm} \times 4 \mathrm{~mm}$, on Anakrom (60/80)

*2 $150 \mathrm{~cm} \times 4 \mathrm{~mm}$, on Gaschrom P $(60 / 80)$

*3 $112.5 \mathrm{~cm} \times 3 \mathrm{~mm}$, on Daichrom C $(80 / 100)$

ほぼ同様な結果が得られる.

サイクラミン酸ナトリウムを亜硝酸分解したときに生 成すると思われる関連物質, $n$ ーアルコールおよびその亜 硝酸エステルの保持時間 $\left(t_{R}\right)$ を Table 1 に表示した. なお脂肪酸メチルエステルは保持時間の参考として同時 に行なった。

Fig. 1-(C) は中間極性カラムとして DEGS と DC550 との両液相を混合して用いた場合である。混合比 1:1 のときのクロマトグラムをここに示した，反応操 作において，サイクラミン酸ナトリウム量に対して亜硝 酸が十分に存在する範囲では C. N. のピークのみが現わ れるのでポリェステル，TCP などの分離のよいカラム で定量することも考えられる。

亜硝酸量が不足するにしたがいシクロへキサノールの ピークが現われてくるようになる。 そこで，この両者の 挙動をも追求したいと考えたが，ポリエステルカラムで は C. N. とシクロへキサノールのピークが離れすぎ, DC-550 カラムでは接近しすぎて分離が不十分であった ので, この両者の中間極性のカラムが適当と考元た. 両 者の混合比 $1: 1$ でこの目的に適するカラムを得た。

中間極性の夜相としては，たとえば QF-1などが考え られるが，一般に QF-1 系統は低濃度液相として高温で 使用する場合が多く，今回は高濃度 $(10 \%)$ カラムとし

て低温 $\left(60^{\circ}\right)$ で使用してみたところ， $n$-デカンおよび $n$-アルコールの亜硝酸エステル, C. N. はテーリングも 少なく比較的よく分離した。 しかしアルコール類はもち ろん脂肪酸メチルェステル類もはなはだしくテーリング が大きく, シクロへキサノールの挙動を追求するために はこのカラムでは不適当であった。

フェノール類に適するといわれる弱極性の TCP を液 相とするカラムの場合には, サイクラミン酸ナトリウム の亜硝酸分解物および関連化合物ともにテーリングがな く, しかも分離のよいクロマトラグムが得られたが, ポ リエステルカラム同様 C. N. とシクローキサノールが離 れすぎ両者の挙動を追求するには適当でない.なお $n$ デカンとC. N.のピークは本実験の条件ではほとんど重 なってしまう。

以上述べたカラム以外に $3.5 \% \mathrm{SE}-30,5 \% \mathrm{SE}-52$, 20\% Carbowax-1500 カラムについても検討したが, SE-30, SE-52 においてはテーリングが大きく使用に適 さなかった.

Carbowax カラムに拈いては C.N. のピークは現わ れずシクロへキサノールに相当するピークのみ現われ た。検液は他のカラムに批る場合と同様に調製したも のであり,このシクロへキサノールに相当するピークは 副生する量をはるかに越える量であり，したがってカラ 
ム内反応によって C. N. が分解してシクロへキサノール を生成すると考えられる。

前述の検液の調製法により，サイクラミン酸ナトリウ ム $5 \mathrm{mg}$, 注入量 $1 \mu \mathrm{l}$, Fig. 1-(C) の条件 (Sensitivity $10^{3}$, RangeV 3.2) で十分安定したクロマトグラムが得 られる.すなわちサイクラミン酸ナトリウムとして $1 \mu \mathrm{g}$ まで再現性よく検出しうる。 また $0.01 \%$ サイクラミン酸 ナトリウム水溶液に垔硝酸ナトリウム結晶を加之， $30 \%$ 硫酸を加えて反応させェーテルで抽出したものを検液と

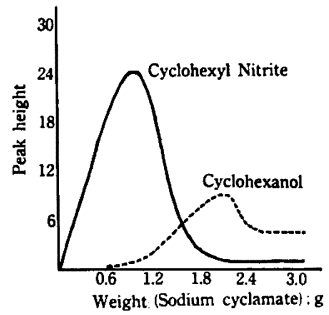

Fig. 2. Relation between amount of sodium cyclamate and the peak height

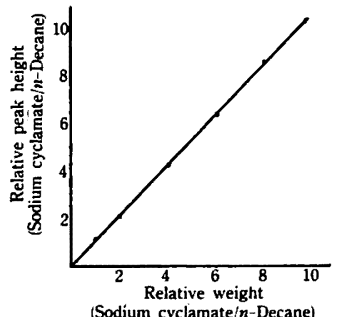

Fig. 3. Calibration curve of sodium cyclamate

Table 2. Reproducibility of Relative Peak Height on Injections of Same Sample

\begin{tabular}{c|c} 
Test numbers & Relative peak height \\
\hline 1 & $\mathrm{C} / \mathrm{D}^{*}$ \\
\hline 2 & 1.6595 \\
3 & 1.6696 \\
4 & 1.7639 \\
5 & 1.6893 \\
1.6750 \\
\hline $\bar{X}$ & 1.6915 \\
\hline$\sigma(\sigma \%)$ & $0.0419(2.48 \%)$
\end{tabular}

* C/D: Cyclohexyl nitrite/n-Decane

Sample: Prepared with $99.98 \mathrm{mg}$ of sodium cyclamate

Conditions: Same as Fig. 1-(C)

Sample size: Approx. $1 \mu 1$
Table 3. Reproducibility of Relative Peak Heighton on Individual Sample

(A)

\begin{tabular}{c|c|c|l} 
No. & $\begin{array}{c}\text { Weight of sodium } \\
\text { cyclamate (mg) }\end{array}$ & \multicolumn{2}{|c}{ Relative peak height } \\
\cline { 2 - 4 } & $\mathrm{C} / \mathrm{D}^{*}$ & $100 / \mathrm{W}^{* *} \times \mathrm{C} / \mathrm{D}$ \\
\hline 1 & 99.14 & 1.5338 & 1.5472 \\
2 & 99.91 & 1.5046 & 1.5060 \\
3 & 101.49 & 1.6017 & 1.5782 \\
4 & 101.25 & 1.5115 & 1.4929 \\
5 & 100.50 & 1.4742 & 1.4669 \\
\hline & $\bar{X}$ & - & 1.5182 \\
\hline & $\sigma(\sigma \%)$ & - & $0.0443(2.92 \%)$
\end{tabular}

(B)

\begin{tabular}{c|c|c|l} 
No. & $\begin{array}{c}\text { Weight of sodium } \\
\text { cyclamate }(\mathrm{mg})\end{array}$ & \multicolumn{2}{|l}{ Relative peak height } \\
\cline { 3 - 4 } 1 & $\mathrm{C} / \mathrm{D}^{*}$ & $300 / \mathrm{W}^{* *} \times \mathrm{C} / \mathrm{D}$ \\
\hline 2 & 302.18 & 2.7921 & 2.7719 \\
3 & 300.41 & 2.7982 & 2.7944 \\
4 & 300.64 & 2.9545 & 2.9483 \\
5 & 301.86 & 2.8108 & 2.8017 \\
\hline & $\bar{X}$ & 2.7757 & 2.7586 \\
\hline & $\sigma(\sigma \%)$ & - & 2.8150 \\
\hline & & $0.0765(2.72 \%)$
\end{tabular}

* C/D: Cyclohexyl nitrite/n-Decane

** W: Weight of sodium cyclamate $(\mathrm{mg})$

Conditions: same as Table 2

Sample size: (A) Approx. $1 \mu \mathrm{g}$

(B) Approx. $0.5 \mu 1$

すれば $0.1 \mu \mathrm{g}$ まで十分に娭出しえた。

$$
\text { 定量 }
$$

1. 亜硝酸量によるクロマトグラムの変化

前述の各カラムおよび使用条件に批るクロマトグラ ムを比較検討した結果，DC-550+DEGS (1: 1) の混合 液相カラムが適当であると考えられたので以下このカラ ムについて実験を行なった。 その結果を Fig. 2 に示し た.

前述のよらに一定量の亜硝酸に対してサイクラミン酸 ナトリウムが比較的少量の場合はほとんど C. N.のピー クのみが現われ，シクロハキサノールのピークはほとん ど認められない.たたし少量のシクロへキセンを副生 し，これについて今回は定量を行なわなかったが反応温 度が高いと増加する傾向にある. フルコール類の亜硝酸 エステルは比較的安定で, 抽出液を藐燥して保存する場 合には十数時間はクロマトグラム上に変化を示さない が，その後徐々に加水分解されて，もとのアルコールに 
なる．アルカリ性で加熱すれば加水分解は顕著である.

一方亜硝酸量に対してサイクラミン酸ナトリウムが多 量の場合にはシクロヘキサノールのピークが顕著に現わ れてくる．このときシクロへキセンの生成量む関係する と思われるが，われわれの使用したカラムおよびその使 用条件では $t_{R}$ がはなはだ早く，したがって溶媒のピー クと重なるか接近して正確に生成量を湘定することは困 難であった。

\section{2. 検量線}

Fig. 2 および 3 に示すよらに内部標準として $n$-デカ ンを用い恰液の調製法に従い操作し検量線を作成すると き，サイクラミン酸ナトリウムとして $600 \mathrm{mg}$ までは良 好な直線性を示した。

\section{3. 定量精度の検討}

前述の検液の調製法に従い，検量線範囲内の 2 点，す なわちサイクラミン酸ナトリウム $100 \mathrm{mg}$ および $300 \mathrm{mg}$ 量について調製した $n$-ヘキサン溶液を用い，同一検液 につき 5 回測定した結果を Table 2 に示した。 また個 タにひょら取し操作した 5 検液につき測定した結果を Table 3-(A) および (B) に示した.

注入操作による機械的なバラッキと，各個別に検液調 製した場合のバラッキとは，相互に近似した結果を示し た. $\pm 3 \%(\sigma \%)$ 程度の誤差を見込むならば十分に信頼し らる定量法として利用することができる。本実験におい ては Sensitivity $10^{3}$, Range V 3.2 6.4 を使用した が，これら機器感度を下げて注入量を增すならば誤差の 幅をさらに小さくすることが可能と考えられる.

4. 混合試料中のサイクラミン酸ナトリウムの定量

混合試料につき Table 2 と同一条件で回収率の測定 を行なった結果を Table 4 に示した。この場合, 同一 処方よりサイクラミン酸ナトリウムを除いた混合試料か

Table 4. Recovery Test of Sodium Cyclamate in Prepared Model Sample

Mixed proportion of sample

\begin{tabular}{|c|c|c|}
\hline \multicolumn{2}{|c|}{ Sodium cyclamate } & $46 \%$ \\
\hline \multicolumn{2}{|l|}{ Saccharin } & 18 \\
\hline \multicolumn{2}{|c|}{ Sodium bicarbonate } & 34 \\
\hline \multicolumn{2}{|l|}{ Corn starch } & 2 \\
\hline \multicolumn{3}{|c|}{ Results of test } \\
\hline \multirow{3}{*}{$\begin{array}{l}\text { Sodium } \\
\text { cyclamate }\end{array}$} & Added & $45.95 \%$ \\
\hline & Found & $46.65 \%$ \\
\hline & Recovery & $101.51 \%$ \\
\hline
\end{tabular}

Conditions: Same as Table 2

Sample size: Approx. $1 \mu \mathrm{l}$
ら調製した検液では，C.N. に相当する付近には全くピ ークを示さなかった。

むす び

サイクラミン酸ナトリウムに，井上らがさきに報告し た赤外法の操作に準じ1)，亜硝酸ナトリウムおよび硫酸 を加えて氷冷時反応させたのち，有機溶剤で抽出し，そ のまま注入してガスクロマトグラフィーを行なった。

DC-550 などの無極性カラムでは，シクロへキサノー ル亚硝酸エステル (C. N.) とシクロへキサノール (C.) のピークは接近して現われるが，極性カラム (DEGS, PEGS, TCP) に上る場合には C. N. と C. は大きく離 れて現われる。

反応操作によって生成する C. N. と C. の両者を観察 するために，DC-550 と DEGS の配合液相カラムを調 製し, 配合比 $1: 1$ において適当なクロマトグラムを得 ることができた。

これらの条件において，亜硝酸が十分二過剩ならば C. N. のピークが主体であって，C. は汪とんど現われな い. 生成した C. N. は安定であり, 再現性むよく $\pm 3 \%$ の誤差で定量への応用も可能である。

承冷時の反応においてはシクロへキセンの生成もごく わずかであったが，これは反応温度によって増加するよ らに思われる.

なお，TCP またはDEGSを液相としたカラムの方が C. N. のピークは尖鋭であり, 検出限界および定量精度 も良好であろらと考えられる。

終わりに臨み, 本研究にご援助いただいた東京薬科大 学藤井清次教授, および国立衛生試験所食品添加物部 林敏夫室長，ならびに実験にご協力いただいた東邦薬科 大学樋口慶子氏に感謝します。

本研究の要旨は第 24 回薬学大会（昭和 42 年 4 月 8 日, 京都) において発表.

文献

1) 上条昌弥, 河村太郎, 井上哲男：食衛誌。7,343 (1966).

2) 厚生省編：“食品添加物公定書”（第 2 版）p. 136 (1966).

3) V. W. Groebel: Z. Lebensm. Untersuch. u. -Forsch. 129, 153 (1966).

4）樋口亮一，小野正之，他：食衛誌. 6,448(1965).

5) D. I. Rees: Analyst 90, 568 (1965).

6) M. L. Richardson, P.E. Luton: ibid. 91, 520 (1966).

7) P. H. Derse, R. J. Daun: J. Assoc. Offic. Anal. Chemists 49, 1090 (1966). 